Article

\title{
Households' Assets Dynamics and Ecotourism Choices in the Western Highlands of Cameroon
}

\author{
Jude Ndzifon Kimengsi ${ }^{1,2, *(1)}$, Mukong Alfred Kechia ${ }^{3,4}$, Balgah Roland Azibo ${ }^{5}$, \\ Jürgen Pretzsch ${ }^{1}$ and Jude Kwei ${ }^{6}$ \\ 1 Institute for Tropical Forestry and Forest Products, Technische Universitat Dresden, \\ 01737 Tharandt, Germany; juergen.pretzsch@forst.tu-dresden.de \\ 2 Department of Geography \& Environmental Studies, Catholic University of Cameroon (CATUC), \\ Bamenda P. O. Box 782, Cameroon \\ 3 Department of Economics, University of Namibia, Windhoek 13301, Namibia; amukong@unam.na \\ 4 Carnegie Fellow, School of Economics, University of Cape Town, Cape Town, Rondebosch 7701, South Africa \\ 5 College of Technology, University of Bamenda, Bambili 39, Cameroon; balgahroland@gmail.com \\ 6 Department of Geography and Planning, University of Bamenda, Bambili 39, Cameroon; \\ judekwei2@gmail.com \\ * Correspondence: jude_ndzifon.kimengsi@tu-dresden.de
}

Received: 13 February 2019; Accepted: 24 March 2019; Published: 27 March 2019

check for updates

\begin{abstract}
Ecotourism is increasingly accepted as a suitable alternative for sustaining rural livelihoods. In spite of this trend, quantitative assessments of relationships between household assets and ecotourism choices, and the policy implications thereof, currently account for only a negligible number of studies in sub-Saharan Africa. This paper contributes to this evidence gap by analyzing the extent to which households' assets drive ecotourism choices on a representative sample of 200 households in Cameroon. The Principal Component Analysis (PCA) and the Human Development Index (HDI) were used to construct indices for ecotourism choices. The ordinary least square and logit models were also employed to estimate the effect of various household assets on ecotourism choices. A high preference was observed for the production and sale of arts and crafts items and the promotion of cultural heritage sites as key ecotourism choices. More women are found to participate in conservation education, as opposed to culture-related activities such as arts and crafts. Access to education and training were inversely related to cultural festival promotion. The results suggest the need to: (i) stem the overdependence on conservation sites for wood supply to the arts and crafts sector, (ii) enforce endogenous cultural institutional regulations, including those that increase female participation in guiding future ecotourism choices. This paper contributes to ecotourism development and conservation theory, with regards to unbundling household level predictors of ecotourism choices, and has implications on the design of policies to implement environmentally less-demanding ecotourism activities.
\end{abstract}

Keywords: ecotourism choices; livelihoods assets; PCA; OLS; conservation; sustainable development; Cameroon

\section{Introduction}

According to World Travel and Tourism Council (WTTC) estimates, travel and tourism's direct contribution to the GDP of the sub-Saharan African region stood at US\$39.7 billion (or 3.1\% of combined regional GDPs). The sector created 4,763,000 jobs-accounting for $2.3 \%$ of total employment in 2011. A significant proportion of this was attributed to ecotourism [1]. By receiving more than 500,000 tourists in 2010, Cameroon was labeled as a tourist destination [2-4]. The country hosts 
numerous ecotouristic attractions, including wildlife sanctuaries, national parks, and forest reserves that span across the country [5]. The Western Highlands of Cameroon has numerous ecotouristic attractions including the Kilum-Ijim Forest Landscape which contains unique flora and fauna [6,7], with over 300,000 people depending on the forest for their livelihoods [8,9]. Ecotourism significantly contributes to rural livelihoods especially through household capital accumulation and overall rural poverty reduction [10-12].

\subsection{Ecotourism and Rural Livelihoods}

Sub-Saharan Africa (SSA) is one of the poorest regions in the world with a significant proportion $(36 \%)$ of its population falling below the poverty line of $\$ 1.25$ per day $[13,14]$. The region depends largely on natural resources for survival [1,15]. Deteriorating welfare levels in this region are even more startling against a backdrop of significant worldwide poverty decline [16,17]. In fact, the Millennium Development Goal (MDG) of halving the proportion of people living below the poverty line was largely unmet in SSA [18]. At the close of the MDGs in 2015, the Sustainable Development Goals (SDGs) continue to emphasize the need to promote conservation and reduce poverty by enhancing livelihoods strategies. For instance, SDG 14 (Conserve and sustainably use the resources for sustainable development) and SDG 15 (Protect, restore, and sustainably manage forests ... and halt biodiversity loss) reiterate the nexus between sustainable livelihoods and natural resource conservation. Unfortunately, high poverty levels in SSA persist amidst significant ecotouristic attractions [1]. This has left scholars and development practitioners with a connection quagmire, given that for a long time now ecotourism development has been recognized as a tool for poverty reduction and sustainable development, since it enhances livelihood options and promotes nature conservation $[10,19,20]$. SSA is home to rich biodiversity and cultural landscapes which represent significant ecotourism assets. During the last decade, this region (SSA) consistently registered one of the highest tourism growth rates, averaging approximately 6\% per annum between 2007 and 2010 [21]. The persistence of poverty in a region with such huge (eco)tourism potentials therefore calls for concern.

The concept of ecotourism cements an intricate relationship between conservation and livelihoods [10,22]. Definitions of this concept could range from passive to active positions, incorporating three interlinked concepts-natural-based, educational, and sustainable (which includes economic and social criteria). These components exhibit both benefits and costs, with an observed disequilibrium in some cases towards greater costs [22-24]. The central tenets of ecotourism were further extended to include components such as (i) nature-based, (ii) preservation/conservation, (iii) education, (iv) sustainability, (v) benefits distribution, and (vi) ethics/responsibility/awareness [22,24]. The popularity of ecotourism is therefore justified, as conservation and development organizations look for a means of generating income from protected areas, and tourist communities seek new ways of reaping maximum benefits [2,10]. Therefore, as a business activity, ecotourism represents a good example of direct monetary values provided by nature $[1,10,21,25]$, making it one of the largest and fastest growing segments of the tourism industry in the last decade [22]. The proposition that (eco)tourism can effectively work as a poverty alleviation tool is alluring, given the significant growth of the sector in poor countries. This has led to may donors, governments, nongovernmental organizations, and conservation agencies to embrace the idea of using (eco)tourism as a poverty alleviation tool [25-27]. Despite this, scientific views on the link between poverty and tourism have varied widely; some viewed it as a modernization strategy, while others emphasize on the significant exclusion of poorer segments of the population in the benefit distribution process $[27,28]$.

Ecotourists are particularly interested in visiting relatively untouched and pristine areas [2,29], with the goal to view, admire, enjoy, learn, and leave limited impact, while serving as a livelihood support or diversification strategy. The evolution of the concept of ecotourism could be traced from the 1980s, which coincides with the grounding of the concept of sustainable development [30,31]. 
This form of tourism was subscribed to because of the increasing environmental concern associated with mass tourism, and tourists' demand for nature-based experiences, which emphasized inequitable tourism benefit sharing, poor linkages, cultural degradation, and the disruption of biodiversity conservation [32-34]. Therefore, focus was slightly tilted away from the sustenance and viability of the tourism industry to the well-being of the local communities and the conservation of biodiversity, which constitute the core of ecotouristic attraction [34-37]. It is therefore a form of community-based tourism which, if well developed, could assist in alleviating alleviate poverty and improving quality-of-life elements for the poor $[35,36]$. The practice is further spurred by the desire to stem the activities of local communities that undermine conservation, such as forest degradation, expanding agricultural frontiers, illegal hunting, logging, firewood collection, and uncontrolled burning $[37,38]$. Through this practice, visitors would patronize local services and respect the customs of the local communities, while local communities have and exhibit the relevant traditional ecological knowledge that support ecotourism [38-41] and provide alternative livelihoods strategies [40-42].

The contribution of ecotourism to rural livelihoods and livelihood diversification has received significant research attention $[25,27,28,41]$. Several studies that employed quantitative approaches have emphasized the role of ecotourism activities as determinants of livelihood outcomes [39-42]. Some scholars have employed Structural Equation Models (SEM) and Choice Experiments (CE) to analyze tourist preferences around conservation sites $[11,25,41]$. In addition, the willingness to pay higher entry fees into ecotouristic sites has been analyzed fairly recently [43]. Irrespective of methodology, most scholars agree that ecotourism contributes to sustaining livelihoods in the recipient communities. However, quantitative assessments of the relationship between household capital- and conservation-related activities (including ecotourism) currently account for only a negligible number of studies [43,44], especially in the context of SSA, where poverty continues to be endemic $[18,44,45]$. This justifies the need for the intensive application of robust quantitative analytical tools to determine such linkages and their policy implications thereof [46-48]. This paper contributes to this evidence gap by analyzing household capital as predictors of ecotourism choices, in the Western Highlands of Cameroon. The term "ecotourism choices" refers to "ecotourism business choices"- denoting the activities in the ecotourism sector which are undertaken by households in the study area, as part of their livelihoods strategy. The research leans on previous research on livelihoods diversification and forest conservation choices in Cameroon, which recognized ecotourism as a tool to support conservation, and unraveled the potential for a quantitative investigation of ecotourism choices [44,49,50].

Recent trends in the Western Highlands of Cameroon indicate that the landscape has benefitted from successful community mobilization efforts to improve its conservation values-a potential asset for ecotourism. However, while studies have focused on qualitatively analyzing the ecotourism potentials and threats in the study area [7], there is a need to not only undertake a quantitative study, but to predict households' ecotourism choices as a function of their assets. This study seeks to contribute to this literature by analyzing the effects of household's livelihoods assets on the ecotourism choices around the Kilum Ijim Forest Landscape (KIFL). Knowledge production in this field has implications for future policies to enhance ecotourism in the study area, with the potential to upscale such efforts in other contexts. The objective of this paper was therefore to estimate the effect of household capital on ecotourism choices around the KIFL. While the sustainable livelihoods framework (SLF) presents five forms of capital, emphasis in this study was on two-financial and human capital. These forms of capital were derived based on preliminary investigations in the study area (see Section 2.2 for details). Therefore, household capital is mirrored through financial capital (income) (Although business types (e.g., ecotourism) affect household income, our focus in this study is to view household capital (e.g., income) and other forms of capital as predictors of ecotourism choices.) and human capital (e.g., education and training). Ecotourism choice variables were adapted from Fennel $[24,30,36]$ to include arts and crafts sales/cultural heritage promotion, wilderness and museum visits, cultural festivals, and conservation education. Indices for ecotourism choices were constructed using Principal Component 
Analysis (PCA) and the Human Development Index (HDI). Further, the ordinary least square and logit models were employed to estimate the effect of various household capital types on ecotourism choices.

\subsection{Ecotourism Dynamics in Cameroon}

Found within SSA and christened as Africa in miniature, Cameroon demonstrates significant potential for ecotourism development. Due to Cameroon's rich biodiversity, it represents almost all ecotones found in Africa including a very wide variety of landscape patterns [51-53]. With a largely intact flora and high fauna diversity, the country is an ecotouristic haven par excellence. In addition, Cameroon presents a good picture of sub-Saharan Africa (SSA) with respect to cultural diversity-having over 250 cultural groups [54,55]. In terms of ethnic diversity, Cameroon's ethnic fractionalization score (0.89) exceeds the SSA average of 0.64 [56]. While the tourism industry and ecotourism, in particular, attracted the attention of the Cameroon government, the industry witnessed a significant decline due to the oil boom. Recent efforts have been introduced to promote ecotourism despite the significant constraints that hinder the growth of the sector [21,51,52].

The current potential of ecotourism in Cameroon, its challenges, and prospects to serve the dual purpose of conservation and livelihood support for local communities have been sufficiently documented $[50,51,57,58]$. Equally, using indicators of resilience, social capital, and collective action, the role of informal microfinance institutions in supporting development led tourism entrepreneurship in Cameroon have equally received scientific attention [59], including through participatory action research [57]. While ecotourism might have not effectively supported livelihoods, scholars have equally been interested in identifying potential alternative livelihood strategies in this regard $[60,61]$. Recent studies have focused on analyzing the alternative livelihood strategies that local community members utilize to insulate themselves against the fragmented nature of the ecotourism industry [2,62-64]. These studies all indicated the umbilical relationship between ecotourism, livelihoods, and livelihoods diversification, justifying the need for a transposition of the variables, with forms of livelihood capital serving as predictors of ecotourism choices. In this study, we modified the analytical variables of the livelihoods framework employed by Kimengsi et al. [44] to focus on financial capital (household per capita income) and human capital (education and training), including household socioeconomic characteristics (age and gender) as predictor variables. The effect of these variables on the outcome variables-ecotourism business choices-considered, in this case, as arts and craft sales/cultural heritage promotion, wilderness and museum visits, cultural festivals, and conservation education, were determined.

\section{Materials and Methods}

\subsection{Study Area}

The Kilum Ijim Forest Landscape (KIFL) (Figure 1) forms one of the over 30 protected areas in Cameroon [5,44]. Totaling 20,000 ha, it contains unique flora and fauna [6,7] with over 300,000 people depending on the forests for their livelihoods $[8,9]$. It is one of the largest remaining West African montane forests and exhibits a high level of endemism in biodiversity, with numerous forest-dependent adjacent communities. Conservation efforts in the landscape began in 1931 (see [6]). Communities around the KIFL have a long history of cultural institutions, and they largely operate on the basis of a traditional centralized political system. Dominant cultural groups here include the Oku, Nso, and Kom $[6,7,44]$. Apart from serving as habitat for endemic biodiversity species, the forests and Lake Oku are attached to endogenous cultural institutions, which further shape their interactions with the forest in their quest for livelihood support. It is on the basis of these potentials that the KIFL is purposively chosen for this study. 


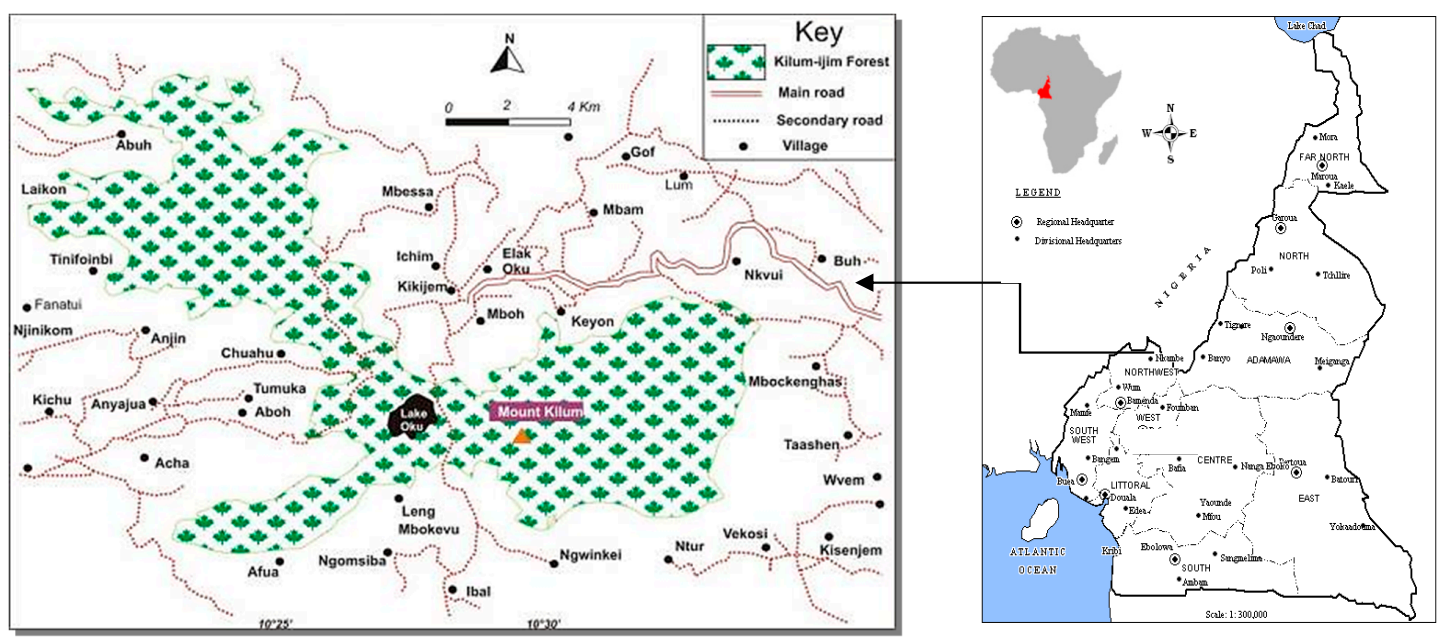

Figure 1. Kilum-Ijim Forest Landscape and adjacent communities (Kilum Project, 2010).

\subsection{Data Collection}

Household's ecotourism choices are a reflection of their assets. The assumption here is that people engage in a range of ecotourism activities for their survival by drawing from a range of livelihood capital types. Livelihood capital is therefore an important determinant of ecotourism choices. In this paper, we focus on analyzing the effect of household capital on ecotourism choices in selected rural communities around the KIFL in Cameroon, with similar forms of capital. The sustainable livelihoods framework (SLF) presents five forms of capital, including natural capital (the quality and quantity of natural resources-ecotouristic attractions), physical capital (e.g., infrastructure-roads and communication channels), social capital (social resources, including networks for cooperation, mutual trust, and support), financial capital (e.g., income and savings), and human capital-education, skills, and available labor [47,51,65]. Based on a pretest of research instruments (December 2017), the key forms of capital and ecotourism activities were identified. For instance, the key ecotouristic attraction (natural capital) in the area_the Kilum Ijim Forest Reserve (KIFR) - is accessed by target communities in the pursuit of their ecotourism activities such as wilderness visits and conservation education. The KIFR equally provides material for cultural festivals and arts and crafts [7]. This capital was therefore not considered critical in defining the ecotourism choices of target households. With a similar infrastructural and communication system (physical capital), and social organization (social capital), most social groups in the study sites demonstrate strong adherence to endogenous cultural institutions. These livelihood capitals were also not crucial in defining ecotourism choices. However, household income levels (financial capital), education, training (human capital), and other household socioeconomic characteristics (age and gender) were judged to have implications for ecotourism choices. We therefore focused on financial and human capital. Also, in the case of ecotourism activities, the four ecotourism choices, adapted from Fennel [24], include arts and crafts, sales/cultural heritage promotion, wilderness and museum visits, cultural festivals, and conservation education. Our unit of analysis is the household where decision making considerations arise based on the asset base.

\subsubsection{Empirical Model}

The nature of the dependent variable in this study allows the use of several estimation techniques to establish and check for the robust effect of livelihood capital on ecotourism choices. The use of different estimation techniques stems from the fact that the multinomial logit (MNL) model deemed appropriate for this study, works well when its key assumption (Independence Irrelevant Alternative (IIA)) is satisfied. In this paper, the IIA is not satisfied. Hence alternative methods (the logit model and the ordinary least square) are employed. The assumption behind this analysis is that households 
choose ecotourism activities to maximize utility given the nature of their capital. The utility function is specified as

$$
U_{i j}=\left(X_{i j} a_{i}+\varepsilon_{i j}\right)>U_{i n}=\left(X_{i n} a_{i}+\varepsilon_{i n}\right) \forall j \neq n
$$

where $U_{i j}$ is the utility to household $i$ for ecotourism choice $j, X_{i j}$ is a vector of household socioeconomic characteristics, $a_{i}$ is a vector of parameters to be estimated, and $\varepsilon_{i j}$ is the random error term. $U_{i n}$ represents the household utility for any other alternative ecotourism choices other than $j$. The reduced form multinomial logit (MNL) is specified as

$$
P_{i j}=\operatorname{Pr}\left(y_{i}=j\right)=\frac{\exp \left(X_{i} a_{j}\right)}{\sum_{n=1}^{J} \exp \left(X_{i} a_{n}\right)}, j=1,2,3, \ldots, J
$$

where $y_{i}$ represents the ecotourism choice available to household $i$. Ecotourism choices are summarized under four (4) categories in this paper-arts and crafts sales/cultural heritage promotion, wilderness and museum visits, cultural festivals, and conservation education. These four categories were judged to be highly visible in the context of the study area. Under the IIA assumption, one would not expect a significant change in the results if one category of the outcome variable is excluded. However, the Hausman test results indicate that the difference between the full and reduced equation is significant, representing a violation of the IIA assumption. To address this limitation, we created an index from the different ecotourism activities following the approach by the UNDP [66] in calculating human development indices. We also employed the Principal Component Analysis (PCA) approach to derive an alternative index. This allowed for the use of the ordinary least square (OLS) to compare the results from the different indices. The Human Development Index (HDI) approach is obtained as follows

$$
\operatorname{Index} A_{i}=\frac{A_{i}-A_{\min }}{A_{\max }-A_{\min }}
$$

where $A_{i}$ is the actual value of an indicator for household $i$, and $A_{\min }$ and $A_{\max }$ are the minimum and maximum values of the indicator for the whole data set (one for arts and crafts sales/cultural heritage promotion and four for conservation education). Based on literature, the ecotourism activities are ranked from the minimum to the maximum. In the data, people were asked to list their most preferred ecotourism choice. The decision of choosing a specific ecotourism activity was further analyzed using the logit model. However, the analysis began with a simple $t$-test, to test for differences in the mean of ecotourism choices and household livelihood capital.

\subsubsection{Data, Sample, and Variables}

Data for this research were generated as part of an ongoing interdisciplinary, mixed-methods research on institutions and livelihood sustenance around forest communities in Cameroon. Earlier studies in this regard applied qualitative approaches to establish the link between participatory forest management and community livelihoods (Kimengsi and Moteka [63]), and recently, a quantitative analysis of livelihood diversification and forest conservation choices [44]. This opened up a research avenue to investigate the effect of household capital (assets) and ecotourism choices. A structured questionnaire, which was developed based on an adapted Poverty Environment Network (PEN) questionnaire [67-69], was designed, with a focus on household financial (e.g., income) and human capital (e.g., education and training). The questionnaire (50 items) took into consideration household socioeconomic status, livelihood capital, and ecotourism choices. The unit of analysis was household, and the respondents were household heads (male and female household heads). Sociodemographic information of the respondents (age, gender, training, income, household size, and education of respondents) was considered in the study. The proposed ecotourism choices include arts and crafts sales/cultural heritage promotion, wilderness and museum visits, cultural festivals, and conservation education. A pretest was conducted during qualitative surveys (December 2017). Eight villages, judged to mirror the key diversification components and located within a $3 \mathrm{~km}$ range from the KIFL, 
were purposively selected for this study. Data were collected from 200 representative households using a systematic sampling design between July and September 2018, targeting every third household in that order, for the villages. Surveys were administered by the first and last author, with the aid of research assistants. To check filled in questionnaires and clarify doubts, daily follow-up was conducted. The contextual knowledge of the research assistants who all originate from this area facilitated trustful communication with the respondents. The data were then coded and entered into a spreadsheet and analyzed using the STATA statistical software version 14.

\section{Results}

\subsection{Household Socioeconomic Characteristics and the Pattern of Ecotourism Participation}

Generally, a majority of the respondents chose arts and crafts sales/cultural heritage promotion $(42 \%)$ and conservation education $(26 \%)$ as their most preferred ecotourism choice. The proportion is relatively small for those who chose cultural festival (13\%) and prefer wilderness/museum visit (19\%). The results suggest a high preference and dependence on the production and sale of arts and craft items, and the promotion of cultural heritage sites for ecotourism practices (See Row 1 of Table 1). Overall, males significantly constitute the majority in most of the ecotourism activities than females. However, the proportion of women in conservation education activities (50\%) is significantly higher than for men $(14 \%)$. This suggests a low level of participation in wood-related arts and craftsmanship for women-since it is muscular labor-demanding. Some craft items are not to be seen or held by women, based on cultural taboos. Over $55 \%$ of respondents with at most primary education compared to $18 \%$ of those with at least secondary education choose arts and craft and the promotion of cultural heritage as their preferred ecotourism choice. Educated household heads were less likely to choose cultural festival promotion and wilderness visits and museums, than the less educated ones. It is surprising that more educated individuals are significantly less likely to choose conservation education, however educated household heads are more likely to choose this activity. A large proportion of respondents who participated in training preferred arts and craft sales and cultural heritage promotion $(61 \%)$ and conservation education (39\%) as their ecotourism choice than those who did not. This suggests the significant role training plays in developing the arts and craft skills of the local population.

Table 1. Descriptive statistics of socioeconomic characteristics according to ecotourism choices.

\begin{tabular}{cccccc}
\hline & & Choice 1 & Choice 2 & Choice 3 & Choice 4 \\
\hline \multirow{2}{*}{ All } & & 0.42 & 0.19 & 0.13 & 0.26 \\
& Male & $(0.49)$ & $(0.39)$ & $0.34)$ & $(0.44)$ \\
Gender & 0.477 & 0.215 & 0.169 & 0.138 \\
& Female & 0.323 & 0.118 & 0.059 & 0.500 \\
Education & Differences & $0.153^{* *}$ & $0.08^{*}$ & $0.110^{* *}$ & $-0.362^{* *}$ \\
& At most primary & 0.554 & 0.031 & 0.046 & 0.369 \\
At least Secondary & 0.176 & 0.471 & 0.294 & 0.059 \\
Education of HH & Differences & $-0.377^{* * *}$ & $0.440^{* * *}$ & $0.248^{* * *}$ & $-0.310^{* * *}$ \\
& At most primary & 0.243 & 0.081 & 0.210 & 0.177 \\
Training & At least Secondary & 0.532 & 0.351 & 0.000 & 0.405 \\
participation & Differences & $0.289^{* * *}$ & $0.271^{* * *}$ & $-0.210^{* * *}$ & $0.263^{* * *}$ \\
& Did not participate & 0.323 & 0.274 & 0.210 & 0.194 \\
& Participated & 0.611 & 0.000 & 0.000 & 0.389 \\
\hline
\end{tabular}

Choice 1 represents arts and crafts/cultural heritage, Choice 2 is wilderness and museum visits, Choice 3 is cultural festivals, and Choice 4 is conservation education. Differences refers to differences in mean of the various factors for a given choice. Standard deviation in parentheses ${ }^{* * *} p<0.01,{ }^{* *} p<0.05,{ }^{*} p<0.1$. 


\subsection{Determinants of Ecotourism Choices (MNL Estimates)}

While the multinomial logit (MNL) model is theoretically appropriate in analyzing the determinants of ecotourism choices, it can only be applied in situations when the Independence of Irrelevant Alternatives (IIA) assumption is satisfied. The IIA assumption of the model presents an expectation of a significant change in the results if one of the categories of the outcome variable is excluded from the model. We ran the full and reduced form models by excluding one of the activities (arts and crafts/cultural heritage), and the results were compared using the Hausman test. The difference in the coefficient between the two models is systemically large. The MNL estimates are presented in Table 3. Our discussion focuses on the estimates presented in Tables 2 and 3. Logit estimates are presented in Table 2, while the OLS and the MNL are presented in Table 3.

Table 2. Logit estimation approach.

\begin{tabular}{|c|c|c|c|c|}
\hline & (1) & (2) & (3) & (4) \\
\hline Variables & Arts/Heritage & Wilder/Museum & Festival & Education \\
\hline \multirow[t]{2}{*}{ Household per capita income } & $0.09^{* *}$ & 0.01 & $-0.12 * * *$ & -0.01 \\
\hline & $(0.04)$ & $(0.03)$ & $(0.01)$ & $(0.03)$ \\
\hline \multirow[t]{2}{*}{ Household size } & $-0.03 *$ & $-0.02 *$ & 0.06 & $0.04^{* * *}$ \\
\hline & $(0.02)$ & $(0.01)$ & $(0.05)$ & $(0.02)$ \\
\hline \multirow[t]{2}{*}{ Number of dependents } & $0.19^{* * *}$ & $0.06^{*}$ & $-0.14^{* *}$ & $-0.15^{* * *}$ \\
\hline & $(0.03)$ & $(0.03)$ & $(0.05)$ & $(0.04)$ \\
\hline \multirow[t]{2}{*}{ Individual is aged 16-25 } & $-0.19 *$ & -1.27 & & $0.61^{* * *}$ \\
\hline & $(0.10)$ & $(87.72)$ & & $(0.07)$ \\
\hline \multirow[t]{2}{*}{ Individual is aged $26-55$} & $-0.24^{* *}$ & $0.13^{*}$ & $-1.03^{* *}$ & $0.69 * * *$ \\
\hline & $(0.10)$ & $(0.07)$ & $(0.50)$ & $(0.11)$ \\
\hline \multirow[t]{2}{*}{ Individual is aged $55+$} & -0.07 & -0.03 & -0.68 & \\
\hline & $(0.11)$ & $(0.09)$ & $(0.50)$ & \\
\hline \multirow[t]{2}{*}{ At least secondary education } & $-0.31^{* * *}$ & $0.28^{* * *}$ & $0.89 *$ & $-0.35^{* * *}$ \\
\hline & $(0.07)$ & $(0.05)$ & $(0.52)$ & $(0.09)$ \\
\hline \multirow[t]{2}{*}{ Individual is female } & $0.19^{* *}$ & 1.26 & -0.05 & $-0.44^{* * *}$ \\
\hline & $(0.08)$ & $(87.72)$ & $(0.07)$ & $(0.07)$ \\
\hline \multirow[t]{2}{*}{ Education of household head } & -0.08 & 1.33 & & $0.14^{*}$ \\
\hline & $(0.08)$ & $(87.72)$ & & $(0.08)$ \\
\hline \multirow[t]{2}{*}{ Participated in formal training } & 0.08 & & & $0.33^{* * *}$ \\
\hline & $(0.08)$ & & & $(0.09)$ \\
\hline Observations & 196 & 124 & 64 & 158 \\
\hline
\end{tabular}

Standard errors in parentheses. ${ }^{* * *} p<0.01,{ }^{* *} p<0.05,{ }^{*} p<0.1$

The results in Table 2 indicate that older individuals have a high probability of choosing conservation education and a low probability of choosing arts and craft/cultural heritage. For example, the probability of choosing conservation education as an ecotourism choice increases by $61 \%$ among individuals aged between 16 and 25, and $69 \%$ for those aged between 26 and 55 than those less than 16 years. The probability of choosing arts and craft/cultural heritage decreases by $19 \%$ and $24 \%$, respectively (see Column 1 and 4 of Table 2). Having at least some secondary education reduces the probability of choosing arts and craft/cultural heritage by $31 \%$ and conservation education by $35 \%$. However, the probability of engaging in wilderness/museum visits and cultural festivals increase by $28 \%$ and $89 \%$, respectively. The results contrast with the case of educated household heads, whose probability of depending on conservation education weakly increased by $14 \%$, and is insignificant for other ecotourism activities. Being female significantly reduces the probability of choosing conservation education for an ecotourism activity by $44 \%$, but increases the probability of choosing arts and craft/cultural heritage by $19 \%$. The probability of choosing arts and craft/cultural heritage significantly increases with household per capita income (9\%) and the number of dependents (19\%). This decreases 
with household size. Participation in training significantly increases the probability of choosing conservation education (33\%).

Table 3. Ordinary least square (OLS) regression analysis for principal component analysis (PCA) and Human Development Index (HDI) and multinomial logit (MNL).

\begin{tabular}{|c|c|c|c|c|c|c|c|}
\hline \multirow[t]{2}{*}{ Variables } & \multicolumn{2}{|c|}{$\begin{array}{c}\text { Principal Component } \\
\text { Analysis }\end{array}$} & \multicolumn{2}{|c|}{$\begin{array}{c}\text { Human } \\
\text { Development Index }\end{array}$} & \multicolumn{3}{|c|}{ Multinomial Logit Estimates } \\
\hline & (1) & (2) & (3) & (4) & (5) & (6) & (7) \\
\hline Household per capita income & & $\begin{array}{c}-0.25^{* *} \\
(0.11)\end{array}$ & & $\begin{array}{l}-0.02 \\
(0.03)\end{array}$ & $\begin{array}{l}-0.06 \\
(0.05)\end{array}$ & $\begin{array}{c}-0.05^{* * *} \\
(0.01)\end{array}$ & $\begin{array}{c}0.00 \\
(0.03)\end{array}$ \\
\hline Household size & & $\begin{array}{l}0.07^{*} \\
(0.04)\end{array}$ & & $\begin{array}{c}0.01 \\
(0.01)\end{array}$ & $\begin{array}{l}-0.02 \\
(0.01)\end{array}$ & $\begin{array}{c}0.02 \\
(0.01)\end{array}$ & $\begin{array}{c}0.05^{* * *} \\
(0.01)\end{array}$ \\
\hline Number of dependents & & $\begin{array}{c}-0.51^{* * *} \\
(0.09)\end{array}$ & & $\begin{array}{c}-0.09^{* * *} \\
(0.02)\end{array}$ & $\begin{array}{c}0.01 \\
(0.02)\end{array}$ & $\begin{array}{c}-0.04 * * \\
(0.02)\end{array}$ & $\begin{array}{c}-0.16^{* * *} \\
(0.04)\end{array}$ \\
\hline Individual is aged 16-25 & $\begin{array}{c}0.16 \\
(0.27)\end{array}$ & $\begin{array}{c}0.77^{* * *} \\
(0.27)\end{array}$ & $\begin{array}{c}-0.30 * * * \\
(0.06)\end{array}$ & $\begin{array}{l}-0.21^{* * *} \\
(0.07)\end{array}$ & $\begin{array}{c}-0.51 \\
(122.61)\end{array}$ & $\begin{array}{c}-0.13 \\
(147.73)\end{array}$ & $\begin{array}{c}0.64 \\
(16.89)\end{array}$ \\
\hline Individual is aged $26-55$ & $\begin{array}{l}0.63^{* *} \\
(0.27)\end{array}$ & $\begin{array}{l}0.82^{* * *} \\
(0.25)\end{array}$ & $\begin{aligned}-0.33^{* * *} \\
(0.06)\end{aligned}$ & $\begin{array}{l}-0.30 * * * \\
(0.06)\end{array}$ & $\begin{array}{c}0.21 \\
(4.72)\end{array}$ & $\begin{array}{c}-0.32 \\
(18.52)\end{array}$ & $\begin{array}{c}0.78^{* * *} \\
(0.15)\end{array}$ \\
\hline Individual is aged $55+$ & $\begin{array}{l}-0.13 \\
(0.30)\end{array}$ & $\begin{array}{c}0.37 \\
(0.28)\end{array}$ & $\begin{array}{l}-0.61^{* * *} \\
(0.07)\end{array}$ & $\begin{array}{l}-0.53^{* * *} \\
(0.07)\end{array}$ & $\begin{array}{c}0.30 \\
(41.22)\end{array}$ & $\begin{array}{c}-0.21 \\
(18.52)\end{array}$ & $\begin{array}{c}-0.73 \\
(594.97)\end{array}$ \\
\hline At least secondary education & $\begin{array}{c}0.60 * * * \\
(0.20)\end{array}$ & $\begin{array}{c}0.59 * * * \\
(0.19)\end{array}$ & $\begin{array}{c}0.10 * * \\
(0.05)\end{array}$ & $\begin{array}{l}0.08^{*} \\
(0.05)\end{array}$ & $\begin{array}{c}0.10 \\
(4.72)\end{array}$ & $\begin{array}{c}0.27 \\
(18.52)\end{array}$ & $\begin{array}{c}-0.17 * * * \\
(0.06)\end{array}$ \\
\hline Individual is female & $\begin{array}{c}-0.42 * \\
(0.22)\end{array}$ & $\begin{array}{c}-0.72^{* * *} \\
(0.21)\end{array}$ & $\begin{array}{c}-0.33^{* * *} \\
(0.05)\end{array}$ & $\begin{array}{c}-0.38^{* * *} \\
(0.05)\end{array}$ & $\begin{array}{c}0.58 \\
(116.71)\end{array}$ & $\begin{array}{l}-0.04 \\
(7.20)\end{array}$ & $\begin{array}{c}-0.47 \\
(16.89)\end{array}$ \\
\hline Education of household head & $\begin{array}{c}0.36 \\
(0.23)\end{array}$ & $\begin{array}{c}0.24 \\
(0.21)\end{array}$ & $\begin{array}{l}-0.06 \\
(0.05)\end{array}$ & $\begin{array}{l}-0.08 \\
(0.05)\end{array}$ & $\begin{array}{c}0.81 \\
(117.35)\end{array}$ & $\begin{array}{l}-0.51 \\
(48.57)\end{array}$ & $\begin{array}{c}0.10 \\
(16.89)\end{array}$ \\
\hline Participated in formal training & $\begin{array}{c}0.06 \\
(0.22)\end{array}$ & $\begin{array}{l}-0.14 \\
(0.22)\end{array}$ & $\begin{array}{c}0.07 \\
(0.05)\end{array}$ & $\begin{array}{c}0.04 \\
(0.05)\end{array}$ & $\begin{array}{c}-0.48 \\
(120.99)\end{array}$ & $\begin{array}{c}-0.19 \\
(144.07)\end{array}$ & $\begin{array}{c}0.47 \\
(16.68)\end{array}$ \\
\hline Constant & $\begin{array}{l}-0.31 \\
(0.26)\end{array}$ & $\begin{array}{l}2.50 * * \\
(1.16)\end{array}$ & $\begin{array}{c}0.98^{* * *} \\
(0.06)\end{array}$ & $\begin{array}{c}1.32^{* * *} \\
(0.28)\end{array}$ & & & \\
\hline Observations & 196 & 196 & 196 & 196 & 196 & 196 & 196 \\
\hline R-Squared & 0.20 & 0.35 & 0.55 & 0.60 & & & \\
\hline
\end{tabular}

Note that results in Columns (1) and (2) are estimates of the effects of socioeconomic characteristics on ecotourism choices. The index is created using the principal component analysis (PCA) and estimated using Ordinary Least Square (OLS). Columns (3) and (4) are estimates of the effects of socioeconomic characteristics on the ecotourism choices. The index is created using the Human Development Index (HDI) approach and estimated using Ordinary Least Square (OLS). Columns (5) to (7) are marginal effect estimates with arts/heritage as base category. Column (5) is wilder/museum, (6) is festival, and (7) is education. The base category for age is less than 16 years, at most primary education for education, female for gender, and nonparticipation for formal training. Standard errors in parentheses ${ }^{* * *} p<0.01,{ }^{* *} p<0.05,{ }^{*} p<0.10$.

\subsection{Determinants of Ecotourism Choices (the PCA and HDI Indices)}

The ordinary least square (OLS) results are presented in Columns 1 to 4 of Table 3. The Table shows some great deviation in the results obtained from the Principal Component Analysis (Columns 1 and 2 of Table 3) and the Human Development (HDI) index (Columns 3 and 4 of Table 3). However, some of the results are similar. For instance, having many household dependents and being female contribute significantly and negatively to the variation in the ecotourism choice index in both cases (see Columns 2 and 4 of Table 3). Being more educated contributes positively to variations in the ecotourism choice index in both cases (see Column 2 of Table 3). In contrast, being older increases the variation in ecotourism activities when the PCA is considered, but this reduces with the HDI. Household income is significant under the PCA but not HDI.

For results in Columns 3 and 4 of Table 3, high values of the index imply highly valued ecotourism activities. The results indicate household size is a negative contributor to the choice of high valued ecotourism activities. Holding other factors constant, a unit increase in household size, significantly reduced the choice of highly valued ecotourism activities by $9 \%$. Being older contributes negatively to the choice of high valued ecotourism activities. For instance, individuals aged 16-25 are 21 to 30\% less likely to choose highly valued ecotourism activities than those of age less than 16 years. Individuals aged 26-55 are 30 to $33 \%$ less likely to choose highly valued ecotourism activities than those of age less than 16 years. The age group of fifty-five and above shows a 53 to $61 \%$ lower likelihood of choosing high valued ecotourism (see Columns 3 and 4 of Table 3 for comparisons). Females are 
33-38\% less likely to sue for high valued ecotourism activities. The level of education of the individual increases the variation in the index. Having at least secondary education increases the choice of high valued ecotourism activities between 8 and 10\%. Household size and household per capita income had no significant influence on the HDI index, but the reverse is true when the PCA index is considered. Participating in formal training and the level of education of the household head was not significant on both indices. Under ecotourism activities, the Independence of Irrelevant Alternatives (IIA) assumption is not satisfied. Hence, the MNL results were not interpreted (Columns 5 to 7 of Table 3).

\section{Discussion}

This paper sought to estimate the effect of household capital (assets) on ecotourism choices. In this regard, we captured household livelihood capital, using financial (income) and human capital (education and training). Ecotourism choices were defined as including arts and crafts sales/cultural heritage promotion, wilderness/museum visits, cultural festivals, and conservation education. We systematically drew a representative sample of 200 households from eight villages around the Western Highlands of Cameroon. We employed the Principal Component Analysis (PCA) and the Human Development Index (HDI) to construct indices (measures) for ecotourism choices. The ordinary least square and the logit model were used to estimate ecotourism choice as a function of household capital. The results suggest a high preference and dependence on the production and sale of arts and crafts items and the promotion of cultural heritage sites for ecotourism practices. This preference and dependence has been observed in difference parts of the world where objects of historical and cultural heritage serve as important forms of capital for income and employment generation [70-74]. In the context of the Western Highlands of Cameroon, arts and crafts have been reported to be the most important touristic attraction and employment generator [71]. The region demonstrates significant potentials for arts and craftsmanship. This has led to the extensive development of arts and craft items, which are linked to the history and culture of the people. Such items are usually exhibited around palaces, cultural centers and museums in the communities, while others of limited cultural attachments are sold to tourists [62,71,75,76]. Most of these items however are carved out of wood, suggesting a high dependence on timber for the promotion of arts and crafts. This argument aligns with previous contentions that although the practice of ecotourism may contribute to income generation and improved well-being, we should not lose sight of its negative impact on conservation through unintended or overlooked side effects $[73,76,77]$. A policy shift towards the promotion of forest plantation-friendly arts and craftsmanship should be a way forward. As this practice is linked to endogenous cultural institutions, there is a need to investigate the role of institutions in shaping the dependence on conservation sites to acquire raw materials for the arts and the craft sector.

The participation of women in conservation education (50\%) is higher than for the men (14\%), while very few women engage in arts and crafts/cultural heritage promotion. However, the logit estimates suggest that being female increases the probability of choosing arts and craft/cultural heritage promotion and reduces the probability of choosing conversation education. This result shows limited female participation in other ecotourism activities, and could be linked to a number of issues: (i) wood-related arts and craftsmanship is muscular labor-demanding-very few women have the strength to engage in such activities-(ii) endogenous cultural institutions (norms and taboos) linked to cultural festivals generally limit the participation of women, especially when it has to do with display of certain masquerades which are considered harmful to women. Multiple cases across tropical Africa [76,78-80], Asia, and Latin America have established significant gender differences in the collection and utilization of forest products, supporting the claim that there are distinctive "male" and "female" roles associated with the collection and use of forest products, especially in its use to produce arts and crafts items $[77,80]$. Based on endogenous cultural institutional consideration and perception, women are not supposed to set eyes on particular cultural items and masquerades that can have severe 
repercussions for them (including failure to conceive). Such strong endogenous cultural institutions hinder the effective participation of women in a wide range of ecotourism promotion activities [71]. Community-specific cultural institutional reforms that consider increasing women representation and participation in guiding future ecotourism activities are necessary to optimize the benefits derived from ecotourism, and to promote the sustainable management of already affected conservation sites.

The results also suggest that as the educational attainment of household heads increase, these members were less likely to promote cultural festival and wilderness/museum visits. This suggests less adherence to cultural attachments with increasing levels of educational attainment. The relationship between education and cultural practices have been largely inverse [76,81], with more educated and/or younger persons having a greater tendency to view the ecological resources from a practical perspective, rather than from a spiritual perspective [81]. This position, which agrees with the dominance of exogenous institutions, led to the virtual suppression, systematic breakdown, and/or transformation of endogenous cultural institutions, and has been blamed for failed natural resource management outcomes in most parts of sub-Saharan Africa [76,82-84], including Cameroon [78,80]. In rural African communities, both educated and less educated people do not only perceive natural resources as sources of food and other domestic products, but they also form the basis for cultural beliefs [85-87]. This suggests a careful consideration of the potentials for endogenous cultural institutions to shape conservation-related activities (such as ecotourism). As ecotourists continue to admire such natural and cultural features, their investments should also target the promotion of strong institutions and their coexistence with formal ones to guarantee the sustainability of ecotouristic sites.

Members who receive training are more likely to choose arts and crafts sales/cultural heritage promotion (61\%) and conservation education (39\%) than those who did not. This suggests the significant role training plays in developing the arts and craftsmanship skills of the local population. Previous studies have indicated unclear relationships between training and education on the one hand, and the level of participation in arts and craft promotion on the other hand, although the role of the latter on employment and income generation has been significantly highlighted [88,89]. However, it can be concluded that their capacities and capabilities were enhanced through education, and training contributes to enhance the survival practices (including ecotourism) for the rural poor [88,89]. This positive influence of education and training on rural livelihoods and conservation strategies are well documented in different sub-Saharan African contexts [90,91]. Policy considerations to promote effective training on methods to optimize forest products in the arts and crafts sector, including the development of forest plantation schemes to supply wood for the sector, are relevant to stem the dependence on conservation sites for wood.

The probability of choosing arts and crafts/cultural heritage significantly increase with household per capita income $(9 \%)$ and number of dependents $(19 \%)$, but decreases with household size. The practice of arts and crafts is usually linked to the exploitation of timber from forest reserves and or plantation forests. This process is demanding in terms of time, energy, and financial resources. Therefore, apart from the endogenous cultural institutional barriers linked to participation (especially female participation), the financial capability of households equally defined their pattern of involvement in ecotourism. It follows that households with lower income tend to avoid such financially demanding practices, while they become more inclined to it as their income levels increase. It should however be noted that income alone is not sufficient to encourage conservation practices such as ecotourism; other factors, such as age, education, well-being, religion, and cultural norms, influence behavior and tend to significantly influence ecotourism participation [64,92]. This too is linked to national and international policy perspectives which tend to brand particular activities as economically viable, feasible, and environmentally friendly. While training significantly increases the probability of choosing conservation education (33\%), the PCA and HDI results indicate that household size and household per capita income have no significant influence on ecotourism choices, while being older and being more educated contributes positively to variations in ecotourism choices. 


\section{Conclusions}

This paper explored the effects of households' livelihood capital (assets) on ecotourism choices in the Western Highlands of Cameroon. Based on the results discussed, the following conclusions are drawn. First, there is a high preference and dependence on the production and sale of arts and craft items, and the promotion of cultural heritage sites as key ecotourism choices in the study sites. Therefore, interventions that promote the introduction of forest plantations to ensure a steady supply of raw materials for the arts and crafts sector, while stemming the high dependence on conservation sites should be explored. This should be further backed by the enforcement of endogenous cultural institutions, to regulate this practice. Second, women are more likely to participate in conservation education, as opposed to culture-related activities such as arts and crafts/cultural heritage promotion. Culture-related activities are either implicitly or explicitly restricted for women by cultural norms. Third, access to education and training showed an inverse relationship with the promotion of cultural festivals and wilderness/museum visits. A careful consideration of the potentials of endogenous cultural institutions (objects, values, and beliefs) in shaping ecotourism in the Western Highlands of Cameroon is required. Policy considerations are needed along the following areas. Firstly, to stem the high dependence on conservation sites for wood supply to the arts and craft sector, by promoting the expansion of forest plantations. Secondly, to promote effective training on the optimization of forest products in the arts and crafts sector. The third intervention should focus on enforcing endogenous cultural institutions, to regulate this practice, while the fourth should be geared towards establishing endogenous cultural institutional reforms that consider increasing women representation and participation in guiding future ecotourism activities in a bid to optimize ecotourism benefits, and to promote the sustainable management of conservation sites. While the concept and context of ecotourism continues to evolve under contestation, theories of ecotourism development hold that this practice has been sufficiently used to predict household and community well-being (development) - not the other way round [32,33,93-95]. The conclusion from this paper does not only contribute to theories of ecotourism development, by unbundling household level predictors of ecotourism choices, but has implications on the design of policies to sustainably manage conservation sites.

Author Contributions: Conceptualization, Design of Research Instruments, Data Collection, Writing-Original Draft Preparation, J.N.K.; Analyzing Data, Writing—Review and Editing, M.A.K.; Writing—Review and Editing, B.R.A.; Review of Draft Manuscript and Supervision, J.P.; Data Collection, Review of Draft Manuscript, J.K.

Funding: This research was funded under the Excellence Initiative Grant of the Technische Universitat Dresden (Grant ID: F-003631-553-U1G11170701), financed by the German Research Foundation (DFG).

Acknowledgments: We deeply acknowledge the household representatives who took time to provide the relevant data by responding to the questionnaire. Many thanks to the research assistants who supported the data collection process. We equally thank the anonymous reviewers whose comments enriched the paper.

Conflicts of Interest: The authors declare no conflict of interest.

\section{References}

1. Snyman, S. The impact of ecotourism employment on rural household incomes and social welfare in six southern African countries. Tour. Hosp. Res. 2014, 1-16. [CrossRef]

2. Kimengsi, J.N. Threats to Ecotourism Development and Forest Conservation in the Lake Barombi Mbo Area (LBMA) of Cameroon. J. Int. Wildl. Law Policy 2014, 17, 213-230. [CrossRef]

3. Bahri-Domon, Y. Cameroon bolsters its hospitality sector. Business in Cameroon, July-August 2018; 65-66.

4. UNWTO. International Tourism Trends 2017, Tourism Highlights 2018 Edition. Available online: https: / / www.e-unwto.org/doi/pdf/10.18111/9789284419876 (accessed on 21 March 2019).

5. Lambi, C.M.; Kimengsi, J.N.; Kometa, C.G.; Tata, E.S. The Management of Protected Areas and the Sustenance of Local Livelihoods in Cameroon. Environ. Nat. Resour. Res. 2012, 2, 10-18.

6. FAO. Case Study of Exemplary Forest Management in Central Africa: Community Forest Management at the Kilum-Ijim Mountain Forest Region Cameroon; FAO: Rome, Italy, 2002. 
7. Fogwe, Z.N.; Kwei, J. Cameroonian protected Kilium-Ijim forests for the development of Oku forest fringe community. J. Environ. Res. Manag. 2015, 6, 293-303.

8. Nurse, M.C.; McKay, C.R.; Young, J.T.; Asanga, C.A. Biodiversity Conservation through Community Forestry, in the Montane Forests of Cameroon; RDFN Paper 18d; Spring; Overseas development Institute: London, UK, 1995.

9. Tata, E.S. Double Decades of Existence of the Kilum-Ijim Community Forest in Cameroon: What Conservation Lessons? J. Int. Wildl. Law Policy 2015, 18, 223-243.

10. Langoya, C.D.; Long, C. Local Communities and Ecotourism Development in Budongo Forest Reserve, Uganda; Rural Development Forestry Network, at 1, Paper 22e; Winter; Overseas development Institute: London, UK, 1998.

11. Juutinen, A.; Mitani, Y.; Mäntymaa, E.; Shoji, Y.; Siikamäki, P.; Sventom, R. Combining ecological and recreational aspects in national park management: A choice experiment application. Ecol. Econ. 2011, 70, 1231-1239. [CrossRef]

12. Qian-Qian, L.; Man, Y.; Xiao-Lin, W. Poverty reduction within the framework of SDGs and Post-2015 Development Agenda. Adv. Clim. Chang. Res. 2015, 6, 67-73.

13. Go, D.; Nikitin, D.; Wang, X.; Zou, H. Poverty and Inequality in Sub-Saharan Africa: Literature Survey and Empirical Assessment. Ann. Econ. Financ. 2007, 8, 251-304.

14. Sahn, D.E.; Younger, S. Living Standards in Africa. Initiative for Policy Dialogue Working Paper Series. May 2009. Available online: http:/ / policydialogue.org/files/publications/Ch_15_Sundaram_Tendulkar.pdf (accessed on 20 June 2017).

15. Barbier, E. Poverty, development and environment. Environ. Dev. Econ. 2010, 15, 635-660. [CrossRef]

16. UNDP. Human Development Report. Beyond Scarcity: Power, Poverty E The Global Water Crisis; UNDP: New York, NY, USA, 2007.

17. Agrawal, A.; Redford, K. Poverty, Development, And Biodiversity Conservation: Shooting in the Dark? Wildlife Conservation Society, Working Paper No. 26. 2009. Available online: http://www.wcs.org/scienc (accessed on 15 November 2018).

18. Sembene, D. Poverty, Growth, and Inequality in Sub-Saharan Africa: Did the Walk Match the Talk under the PRSP Approach? IMF Working Paper. 2015. Available online: https://www.imf.org/external/pubs/ft (accessed on 20 June 2017).

19. Brandon, K. Ecotourism and Conservation: A Review of Kev Issues; Biodiversity Ser. Paper No. 033; The World Bank: Washington, DC, USA, 1996.

20. Kaffashi, S.; Radam, A.; Shamsudin, M.N.; Yacob, M.R.; Nordin, N.H. Ecological Conservation, Ecotourism, and Sustainable Management: The Case of Penang National Park. Forests 2015, 6, 2345-2370. [CrossRef]

21. Kimbu, A.S. The Challenges of Marketing Tourism Destinations in the Central African Subregion: The Cameroon Example. Int. J. Tour. Res. 2014, 13, 324-336. [CrossRef]

22. Diamantis, D. The concept of ecotourism: Evolution and trends. Curr. Issues Tour. 1999, 2, 93-122. [CrossRef]

23. Donohoe, H.M.; Needham, R.D. Ecotourism: The evolving contemporary definition. J. Ecotour. 2006, 5, 192-210. [CrossRef]

24. Fennel, D.A. A content analysis of ecotourism definitions. Curr. Issues Tour. 2001, 4, 403-421. [CrossRef]

25. Hein, L. Economic benefits generated by protected areas: The case of the Hoge Veluwe forest, the Netherlands. Ecol. Soc. 2011, 16, 13. [CrossRef]

26. Liu, C.; Xiao, W.; Li, J.; Pechacek, P. Attitude of tourists visiting nature reserves in China. Tour. Manag. Perspect. 2013, 5, 1-4. [CrossRef]

27. Scheyvens, R. Exploring the Tourism-Poverty Nexus. Curr. Issues Tour. 2007, 10, 231-254. [CrossRef]

28. Truong, V.D.; Hall, M.C.; Garry, T. Tourism and poverty alleviation: Perceptions and experiences of poor people in Sapa, Vietnam. J. Sustain. Tour. 2014, 22, 1071-1089. [CrossRef]

29. Buckley, R. Ecotourism: Principles and Practices; CAB International: London, UK, 2009.

30. Fennell, D. Ecotourism: An Introduction, 3rd ed.; Routledge: New York, NY, USA, 2008.

31. Mowforth, M.; Munt, I. Tourism and Sustainability, 2nd ed.; Routledge: New York, NY, USA, 2003.

32. Wearing, S.; Neil, J. Ecotourism: Impacts, Potential and Possibilities? 2nd ed.; Butterworth-Heinemann: London, UK, 2009.

33. Caria, J.; Calfucura, E. Ecotourism and the development of indigenous communities: The good, the bad, and the ugly. Ecol. Econ. 2012, 73, 47-55. [CrossRef] 
34. Zeppel, H. Indigenous Ecotourism: Sustainable Development and Management; CABI: Wallingford, UK, 2006.

35. Dodds, R.; Ali, A.; Galaski, K. Mobilizing knowledge: Determining key elements for success and pitfalls in developing community-based tourism. Curr. Issues Tour. 2018, 21, 1547-1568. [CrossRef]

36. Fennell, D. Ecotourism and the myth of indigenous stewardship. J. Sustain. Tour. 2008, 16, 129-149. [CrossRef]

37. Stronza, A.; Gordillo, J. Community views of ecotourism. Ann. Tour. Res. 2008, 35, 448-468. [CrossRef]

38. Mitchell, J.; Ashley, C. Tourism and Poverty Reduction: Pathways to Prosperity; Earthscan: London, UK, 2010.

39. Mitchell, J. Value chain approaches to assessing the impact of tourism on low-income households in developing countries. J. Sustain. Tour. 2012, 20, 457-475. [CrossRef]

40. Muchapondwa, E. The Economics of Community-Based Wildlife Conservation in Zimbabwe. Ph.D. Thesis, Goteborg University, Goteborg, Sweden, 2003.

41. Bandyopadhyay, S.; Shysamsundar, P.; Wang, L.; Humavindu, M.N. Do Households Gain from Community-Based Natural Resource Management? An Evaluation of Community Conservancies in Namibia; DEA Research Discussion Paper, No. 68; The World Bank: Washington, DC, USA, 2004. [CrossRef]

42. Turpie, J.; Barnes, J.; Arntzen, J.; Nherera, B.; Lange, G.-M.; Buzwani, B. Economic value of the Okavango Delta, Botswana, and implications for management. Okavango Development Management Plan. 2006. Available online: http://www.anchorenvironmental.co.za/Documents/Pdfs/Okavango\% 20Delta\%20Valuation\%20FINAL\%20REPORT\%202006.pdf (accessed on 16 November 2018).

43. Thapa, B.; Parent, G. Tourists' willingness to accept/pay increased entry fees for park improvement projects. Curr. Issues Tour. 2018, 1-5. [CrossRef]

44. Kimengsi, J.N.; Pretzsch, J.; Mukong, A.K.; Ongolo, S. Measuring Livelihood Diversification and Forest Conservation Choices: Insights from Rural Cameroon. Forests 2019, 10, 81. [CrossRef]

45. Endamana, D.; Shepherd, G.; Neba, G.A.; Angu, K.A.; Bonito, C.N.; Ako, C.E. Rapid Assessment of the Value of Forest Income for People in Central Africa. J. Sustain. For. 2018. [CrossRef]

46. Van den Berg, M. Household income strategies and natural disasters: Dynamic livelihoods in rural Nicaragua. Ecol. Econ. 2010, 69, 592-602. [CrossRef]

47. Jiao, X.; Pouliot, M.; Walelign, S.Z. Livelihood Strategies and Dynamics in Rural Cambodia. World Dev. 2017, 97, 266-278. [CrossRef]

48. Walelign, S.Z.; Pouliot, M.; Larsen, H.O.; Smith-Hall, C. Combining household income and asset data to identify livelihood strategies and their dynamics. J. Dev. Stud. 2017, 53, 769-787. [CrossRef]

49. Ndenecho, E.N. Habitat Loss and the survival of endemic montane forest avifauna of the Bamenda Highlands, Cameroon. J. Environ. Sci. 2006, 10, 1-16.

50. Ndenecho, E.N. Ecological Planning and Ecotourism Development in Kimbi Game Reserve, Cameroon. J. Hum. Ecol. 2009, 27, 105-113.

51. Mushongah, J.; Scoones, I. Livelihood change in rural Zimbabwe over 20 years. J. Dev. Stud. 2012, 48, 1241-1257. [CrossRef]

52. Harilal, V.; Tichaawa, T.M. Ecotourism and Alternative Livelihood Strategies in Cameroon's Protected Areas. EuroEconomica 2018, 1, 133-148.

53. Schmitz, S.; Tsobgou, D.L. Developing tourism products and new partnerships through participatory action research in rural Cameroon. Geogr. Res. 2016, 54, 2. [CrossRef]

54. Yenshu, E.V. Ethnicisation du domaine public et construction de l'état: Pistes pour transcender une antinomie. Afrique et Développement 2011, 36, 249-275.

55. Egute, T.O. Modern law and local tradition in forest heritage conservation in Cameroon: The Case of Korup. Ph.D. Thesis, Environmental Sciences Brandenburg University of Technology, Cottbus, Germany, 2012.

56. Fearon, J.D. Ethnic structure and cultural diversity by country. J. Econ. Growth 2003, 8, 195-222. [CrossRef]

57. Behrens, J. The Potential for Ecotourism in Cameroon-a stakeholder analysis. In Beiträge zum Nachhaltigen Tourismus, Schriftenreihe der Fachhochschule Eberswalde; Lichtenberg, T.J., Ed.; Mensch \& Buch Verlag: Berlin, Germany, 2005.

58. Balgah, S.N.; Nfor, F. An Assessment of Ecotourism Potentials in Kupe Muanenguba Division, South West Region, Cameroon. Int. Journal of English, Literature and Social Sciences 2017, 2, 63-75.

59. Ngoasong, M.Z.; Kimbu, A.N. Informal microfinance institutions and development-led tourism entrepreneurship. Tour. Manag. 2016, 52, 430-439. [CrossRef] 
60. Barrett, C.; Reardon, T.; Webb, P. Nonfarm Income Diversification and Household Livelihood Strategies in Rural Africa: Concepts, Dynamics and Policy Implications. Food Policy 2001, 26, 315-331. [CrossRef]

61. Hanrahan, B. Living Care-Fully: The Potential for an Ethics of Care in Livelihood Approaches. World Dev. 2015, 72, 381-393. [CrossRef]

62. Yunji, R.N. An Examination of Policy and Planning Processes Towards Developing a Comprehensive Plan Applying Rational Tourism Models: The Case of Cameroon, Master of Science in Tourism Management; Eastern Mediterranean University: Gazimağusa, North Cyprus, 2014; unpublished.

63. Kimengsi, J.N.; Ngala, M.P. Revisiting participatory forest management and community livelihoods in the Kilum-Ijim Montane forest landscape of Cameroon. Int. J. Glob. Sustain. 2018, 2, 39-55. [CrossRef]

64. Stem, C.J.; Lassoie, J.P.; Lee, D.R.; Deshler, D.D.; Schelhas, J.W. Community Participation in Ecotourism Benefits: The Link to Conservation Practices and Perspectives. Soc. Nat. Resour. 2003, 16, 387-413. [CrossRef]

65. Scoones, I. Livelihoods perspectives and rural development. J. Peasant Stud. 2009, 36, 171-196. [CrossRef]

66. UNDP. Human Development Report 2014 (Technical Note); United Nations Development Program: New York, NY, USA, 2014.

67. PEN. PEN Prototype Questionnaire Version 4. Poverty Environment Network. 2007. Available online: www.cifor.cgiar.org/pen (accessed on 12 July 2016).

68. PEN. PEN Technical Guidelines Version 4. Poverty Environment Network. 2007. Available online: www. cifor.cgiar.org/pen (accessed on 12 July 2016).

69. Chhetri, B.B.K.; Larsen, H.O.; Smith-Hall, C. Environmental resources reduce income inequality and the prevalence, depth and severity of poverty in rural Nepal. Environ. Dev. Sustain. 2015, 17, 513-530. [CrossRef]

70. Ismagilova, G.; Safiullin, L.; Gafurov, I. Using historical heritage as a factor in tourism development. Procedia-Soc. Behav. Sci. 2015, 188, 157-162. [CrossRef]

71. Kimengsi, J.N.; Lum, A.E. An Analysis of the Potential Development Implications of Cultural Tourism in North West Cameroon. Can. J. Trop. Geogr. 2018, 5, 1-9.

72. Sunderland, T.; Achdiawan, R.; Angelsen, A.; Babigumira, R.; Ichowitz, A.; Paumgarten, F.; Reyes-García, V.; Shively, G. Challenging Perceptions about Men, Women, and Forest Product Use: A Global Comparative Study. World Dev. 2014, 64, 56-66. [CrossRef]

73. Chunhabunyatip, P.; Sasaki, N.; Grünbühel, C.; Kuwornu, J.K.M.; Tsusaka, T.W. Influence of Indigenous Spiritual Beliefs on Natural Resource Management and Ecological Conservation in Thailand. Sustainability 2018, 8, 2842. [CrossRef]

74. Kandari, L.S.; Bisht, V.K.; Bhardwaj, M.; Thakur, A.K. Conservation and management of sacred groves, myths and beliefs of tribal communities: A case study from North-India. Environ. Syst. Res. 2014, 3, 16. [CrossRef]

75. Burgin, S.; Zama, E.F. Community-based tourism-Option for forest-dependent communities in 1A IUCN protected areas? Cameroon case study. In Proceedings of the SHS Web of Conferences, Kola Kinabalu, Malaysia, 9-11 December 2014.

76. Fru, B.S. Contribution of traditional institutions on the sustainable management of sacred forests: Case Study of Mankon Sacred Forests Northwest Region, Cameroon. Master's Thesis, Environmental Management, University of Dschang, Cameroon, Germany, 2014.

77. Anoliefo, G.; Isikhuemhen, O.; Ochije, N. Environmental implications of the erosion of cultural taboo practices in Awka-South local government area of Anambra State, Nigeria: Forests, trees, and water resource preservation. J. Agric. Environ. Ethics 2003, 16, 281-296. [CrossRef]

78. Haller, T. Rules which pay are going to stay: Indigenous institutions, sustainable resource use and land tenure among the Ouldeme and Platha, Mandara Mountains, Northern Cameroon. Bulletin de l'APAD. 2001, mis en ligne le 20 février 2006, consulté le 29 janvier 2018. Available online: http:/ /journals.openedition. org/apad/148 (accessed on 15 May 2018).

79. Awasom, N.F. The vicissitudes of Twentieth-Century Mankon Fons in Cameroon's changing social order. In The Dynamics of Power and the Rule of Law: Essays on Africa and Beyond, in Honour of Emile Adriaan B van Rouveroyvan Nieuwaal; Van Binsbergen, W., Pelgrim, R., Eds.; LIT Verlag/African Studies Centre: Leiden, The Netherlands, 2003; pp. 101-120.

80. Takor, T.J. The Traditional Institution of Manyu Division, Cameroon (1990-2011): An intersection of chiefs and party politics. Int. J. Sci. Technol. Res. 2017, 6, 102-108. 
81. McClusky, B. Investigating the relationships between education and culture for female students in tertiary settings in the UAE. 2017. Available online: https:/ / ro.ecu.edu.au/theses/1974 (accessed on 15 January 2019).

82. Faye, P. Adding Scepticism About 'Environmentality': Gender exclusion through a natural resources collectivization initiative in Dionewar, Senegal. In Drylands Forests: Management and Social Diversity in Asia and Africa; Bose, P., van Dijk, H., Eds.; Springer: Cham, Switzerland, 2016; pp. 95-114.

83. Udgaonkar, S. The recording of traditional knowledge: Will it prevent "bio-piracy"? Curr. Sci. 2002, 82, 413-419.

84. Ensminger, J. Making a Market. The Institutional Transformation of an African Society; Cambridge University Press: Cambridge, UK, 1992.

85. Yami, M.; Vogl, C.; Hauser, M. Comparing the effectiveness of informal and formal institutions in sustainable common pool resources management in Sub-Saharan Africa. Conserv. Soc. 2009, 7, 153-164. [CrossRef]

86. Ambe, E.L. Rural Tourism as an Alternative Source of Income; A Case Study of Bafut Sub-Division; DIPES I Thesis Unpublished; ENS Bambili, University of Bamenda: Bamenda, Cameroon, 2009.

87. Mukul, S.A.; Rashid, A.M.; Uddin, M.B. The role of spiritual beliefs in conserving wildlife species in religious shrines of Bangladesh. Biodiversity 2012, 13, 108-114. [CrossRef]

88. Sen, A. Development as Freedom; Oxford University Press: Oxford, UK, 1999.

89. Frediani, A.A. Sen's Capability Approach as a framework to the practice of development. Dev. Pract. 2010, 20, 173-187. [CrossRef]

90. Teshome, B.; Edriss, A.-K. Determinants and patterns of Income Diversification among Farmers in Akaki District, Ethiopia. J. Res. Econ. Int. Financ. 2013, 2, 68-78.

91. Maniriho, A.; Nilsson, P. Determinants of Livelihood Diversification among Rwandan Households: The Role of Education, ICT and Urbanization. East Africa Research Papers in Economics and Finance, EARP-EF No. 2018, 24. Available online: https:/ ju.se/download/18.243bd3a4161b08d5c5817888/1520578313123/ EARPEF\%202018-24\%20Maniriho.pdf (accessed on 26 December 2018).

92. Evans, K.; Flores, S.; Larson, A.M.; Marchena, R.; Müller, P.; Pikitle, A. Challenges for women's participation in communal forests: Experience from Nicaragua's indigenous territories. Women Stud. Int. Forum 2017, 65, 37-46. [CrossRef]

93. Ambe, T.E.; Angwafo, T.E.; Tangyie, G.C.; Siri, B.N.; Tita, D.F. Ecological Tourism and Cameroon-Opportunities and Constraints. In Ecotourism: Management, Development and Impact; Krause, A., Weir, E., Eds.; Nova Publishers: New York, NY, USA, 2011; Chapter 4; pp. 113-133.

94. Beeton, S. Community Development through Tourism; Landlinks Press: Collingwood, VIC, Australia, 2006; 255p.

95. Tinsley, R.; Lynch, P.A. Differentiation and tourism destination development: Small business success in a close-knit community. Tour. Hosp. Res. 2014, 8, 161-177. [CrossRef] 